\title{
ANTHOLOGY
}

\section{CAN YOU REMEMBER ANY NOTABLE QUOTATIONS ABOUT ANIMALS?}

Mrs. Diana Spearman, a Council member of the Fauna Preservation Society, is compiling an anthology about various aspects of animals and conservation which will be sold for the benefit of the Fauna Preservation Society and the Universities Federation for Animal Welfare. Quotations, which should be sent direct to Mrs. Spearman, are urgently required. They might relate to :

(1) Man and beast or the ways in which animals enter into the world of man the hunter, the destroyer, the artist, the mystic, the myth-maker or the nature lover and how necessary animals are to him. Examples :

"I do not know how God will judge my handiwork. During the last three weeks I have written more than fifty pages of the score of Parsifal and saved three young dogs from death. We still have to wait and see which lies heavier in the scales."

RICHARD WAGNER.

"No animal is cruel for the sake of cruelty, only man. This makes his character devilish which is much worse than mere beastliness."

ARTHUR SCHOPENHAUER.

(2) Concepts of conservation. As well as modern ideas, the anthologist proposes to include such philosophies as the eighteenth idea of the "great chain of nature". Leibnitz, for instance, observed that "We may believe that God prefers men to lions, but not that $\mathrm{He}$ prefers one man to all lions". Or:

"The fate of animals is of greater importance to me than the fear of appearing ridiculous; it is indissolubly connected with the fate of men."

EMILE Zola.

"Whole aeons of love are required to compensate the animals for the services they have rendered us."

CHRISTIAN MORGENSTERN.

(3) Descriptions in verse or prose of "the animal in its own right". There is, for instance, an account of the birds of paradise in "The Malay Archipelago", by Alfred Russel Wallace, which ends : "This ... must surely tell us that all living things were Nor made for man."

Mrs. Spearman would be very grateful for help in obtaining quotations for all three sections listed above, particularly quotations from biblical, oriental or classical literature such as examples from Herodotus or Pliny. Address : Mrs. Diana Spearman, 7 Lord North Street, London, S.W. 1. 